\title{
ESR GEOCHRONOLOGY OF THE MINJIANG RIVER TERRACES AT WENCHUAN, EASTERN MARGIN OF TIBETAN PLATEAU, CHINA
}

\author{
CHUN-RU LIU ${ }^{1}$, GONG-MING YIN ${ }^{1}$, HUI-PING ZHANG ${ }^{1}$, WEN-JUN ZHENG ${ }^{1}$, PIERRE VOINCHET $^{2}$, \\ FEI HAN ${ }^{1}$, DUO WANG ${ }^{1,3}$, WEI-JUAN SONG ${ }^{1,3}$ and JEAN-JACQUES BAHAIN ${ }^{2}$ \\ ${ }^{I}$ State Key Laboratory of Earthquake Dynamics, Institute of Geology, China Earthquake Administration, Beijing 100029, China \\ ${ }^{2}$ Département de Préhistoire, Muséum National d'Histoire Naturelle, UMR7194 du CNRS, 1 rue René Panhard, 75013 Paris, France \\ ${ }^{3}$ Schools of the Earth Science and Resource, China University of Geosciences, Beijing, 100083, China
}

Received 29 January 2013

Accepted 21 August 2013

\begin{abstract}
The Minjiang River terrace along the Longmen Shan fault zone near Wenchuan, at the eastern margin of the Tibetan Plateau, China, provides archives for tectonic activity and quaternary climate change. However, previous studies were not able to provide ages older than $100 \mathrm{ka}$ due to the limitations of dating material or/and methods applied to date the fluvial sediments. In this study, we used the ESR signal of the Ti-Li center in quartz to obtain the ages of four higher terraces (T3-T6). According to the results, the terraces T3 to T6 were formed at $64 \pm 19 \mathrm{ka}, 101 \pm 15 \mathrm{ka}, 153 \pm 33 \mathrm{ka}$, and $423 \pm 115 \mathrm{ka}$, respectively. Combined with previous studies, these results indicate that the formations of all terraces correspond to glacial/interglacial transition periods, such as, T1-T5 being correlated to MIS2/1, MIS4/3, MIS5d/5c, and MIS6/5e respectively, while T6 probably to MIS12/11. According to these data, it is found that the average incision rate was significantly higher over the last $150 \mathrm{ka}$ than that previous $100 \mathrm{ka}$ ( 250 to $150 \mathrm{ka}$ ). As both tectonics and climate have affected the formation of these terraces, in addition to the overall uplifting of Tibetan Plateau, the regional uplift due to isostasy would be an additional tectonic factor in the formation of river terraces in the eastern margin of Tibetan plateau.
\end{abstract}

Keywords: river terrace, ESR dating, quartz, Minjiang River, Tibetan plateau.

\section{INTRODUCTION}

The uplifting history of the Tibetan Plateau plays a key role in the continuous debate over large-scale linkages between tectonic and global climate change during the Neogene (Kirby et al., 2002; Molnar, 2005). The eastern Tibet takes largest fluvial relief which not only causes the highest incision rate at the edge of this region, but also leads to the additional uplifting following the intensified erosion assuming isostasy (Pinter and Brandon, 2005).

Corresponding author: C-R. Liu e-mail: liuchunru0821@126.com
River terrace sequences furnish some information concerning both tectonic movement and climate change. A single factor or multiple coupled factors lead to the erosion, transport or deposit of fluvial sediments to form a terrace (Li et al., 1996). The tectonic movement and climate change based on the study of river terrace has been becoming a hot topic (Maddy, 1997; Bridgland et al., 2000; Pan et al., 2009).

The river terrace along the margin of the Tibetan Plateau provides hence archives for tectonic activities and climatic changes (Schumm and Parker, 1973), and has been investigated for several decades ( $\mathrm{Li}, 1991$; Porter et al., 1992). For example, Pan et al. (2009) concluded in 
detail the age of terrace sequences of Yellow River at Lanzhou, in the northeastern Tibetan Plateau. The results declaimed that in past 1.2 Ma there were two stage periods for terrace formation in the upper reach of Yellow River, one ranging from 1.2 to $0.83 \mathrm{Ma}$, the other from 0.13 to $0.05 \mathrm{Ma}$, which was correlated to two phases of rapid uplifting, Kunhuang movement and Gonghe movement.

However, the studies at the east margin of the Tibetan Plateau, such as Minjiang River, were faced with the limitations of dating materials or/and methods that have been applied to date these fluvial sediments, such as OSL, $\mathrm{TL}$ and ${ }^{14} \mathrm{C}$ ( $\mathrm{Li}$ et al., 2005, 2006). Cosmogenic dating method $\left({ }^{10} \mathrm{Be}\right)$ has been used to dating the river terrace and got some successful results (Brocard et al., 2003), but the sediment for this method should be very stable after deposition. Moreover, independent chronology by other dating methods is required for quaternary profile.

Electron Spin Resonance (ESR) is a potential dating method for fluvial sediments with the dating range from tens of thousands up to millions of years. In recent years, there has been a strong interest to apply ESR dating to quartz (e.g. Yokoyama et al., 1985; Tanaka et al., 1995; Laurent et al., 1998; Beerten et al., 2006; Rink et al., 2007; Liu et al., 2010a; Voinchet et al., 2004, 2010; Tissoux et al., 2007, 2008; Moreno et al., 2012). So it is worthwhile to use this method to develop the independent chronology for the river terrace at the east margin of the Tibetan Plateau.

In this work, we applied the ESR method to dating of four higher level terraces at the upper reach of the Minjiang River. The quartz Ti-Li center ESR signal (Toyoda et al., 2000; Rink et al., 2007) was used to date the river terrace (T3-T6) samples which could be older than $100 \mathrm{ka}$ assuming an initial zeroing of the signal, because bleaching experiments (Toyoda et al., 2000; Tissoux et al., 2007; Gao et al., 2009) have shown that the quartz Ti-Li center ESR signal can be completely bleached after the equivalent of a few days of direct sunlight exposure, that is very quick for quartz ESR centers. The method promises to provide reliable geochronology for quaternary tectonic uplift and climatic change research.

\section{GEOLOGY AND SAMPLING}

The Longmen Shan marks the transition between the low-elevation Sichuan Basin $(\sim 500 \mathrm{~m})$ and the Tibetan Plateau $(\sim 4000 \mathrm{~m})$ and is characterized by a steep topographic transition (Fig. 1) (Burchfiel et al., 1995; Chen and Wilson, 1996; Chen et al., 2000). It has a complex structure resulting from a complex multiphase history of three main faults, Wenchuan-Maowen Fault, BeichuanYingxiu Fault, Jiangyou-Guanxian Fault (Burchfiel et al., 1995; Chen et al., 1995; Burchfiel et al., 2008). Deformation of the Longmen Shan during Cenozoic time is associated with the Himalayan orogenic cycle and Tibetan Plateau uplift. Despite the rarity of active tectonics markers in this area (Godard et al., 2009), previous studies indicated that the topography in the Longmen Shan apparently developed with minimal shortening of the upper crust during the Tertiary (Dirks et al., 1994; Burchfiel et al., 1995; Royden et al., 1997; Kirby et al., 2002; Zhang et al., 2011). Studies on active faults indicate that the average slip rates (both dip-slip and strike-slip) in tens of millennium time scale are around $1 \mathrm{~mm} / \mathrm{a}$, consistent with decadal GPS observations (King et al., 1997; Chen et al., 2000; Zhang et al., 2004; Ma et al., 2005). Those observations lead to important questions on the nature of tectonic and denudation processes along this margin and their potential interactions. It also is pointed out the Longmen Shan region as a critical target to test the geodynamical models proposed to describe the evolution of the region (Godard et al., 2009).
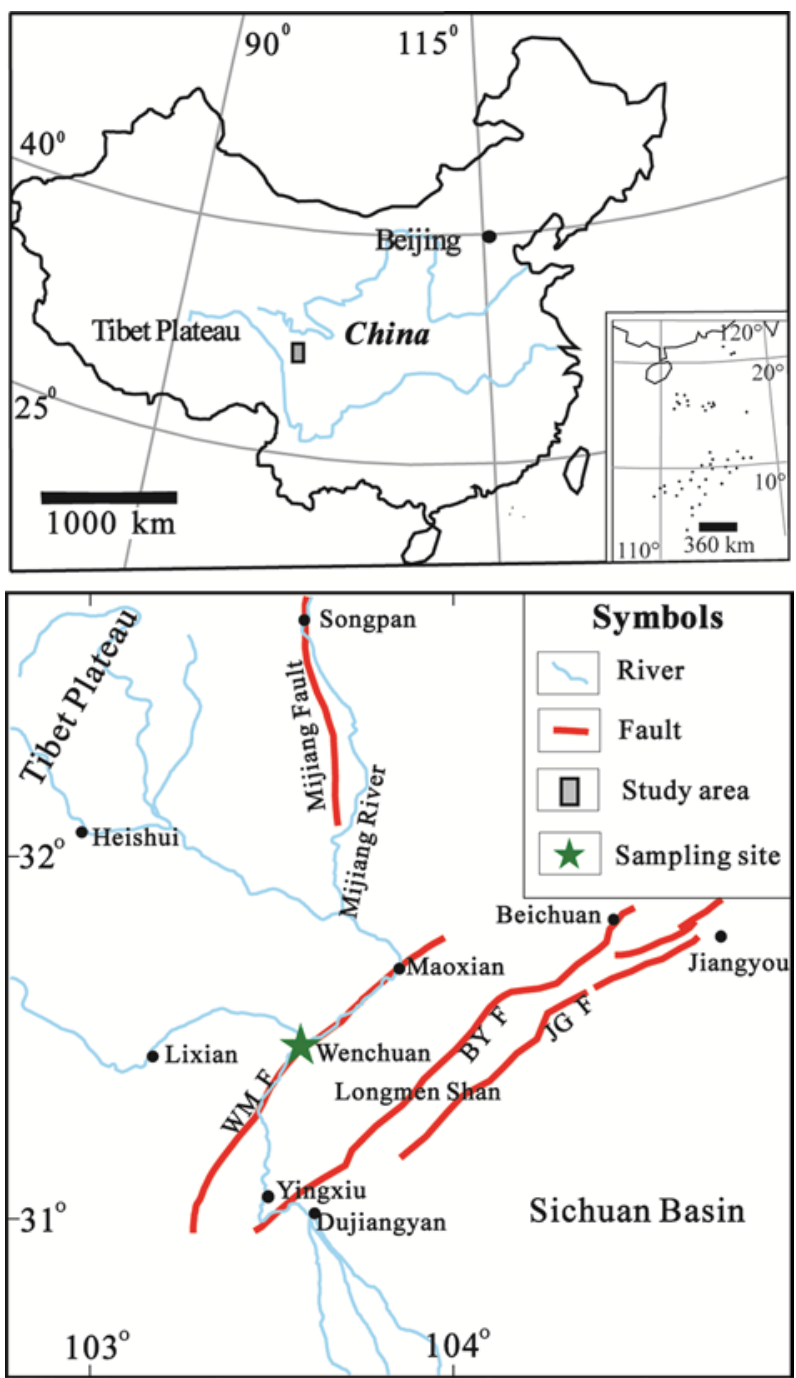

Fig. 1. Location of ESR sampling, Longmen Shan and Mingjiang River, at the east margin of the Tibet Plateau. WM F: Wenchuan-Maowen Fault; BY F: Beichuan-Yingxiu Fault; JG F: Jiangyou-Guanxian Fault. 
The Minjiang River runs along the eastern margin of the Tibetan Plateau, mostly perpendicularly across the Longmen Shan fault zone. Along the upper reach of the Minjiang River, characterized by sharp V-type valleys, at least six level terraces were developed. A part of these were previously dated by TL or ${ }^{14} \mathrm{C}$ method ( $\mathrm{Li}$ et al., 2005; Ma et al., 2005). Li et al. (2005) identified five level terraces, from $\mathrm{T} 1$ to $\mathrm{T} 5$, and gave the ages of $\mathrm{T} 1$ to $\mathrm{T} 3$ by $\mathrm{TL}$ and ${ }^{14} \mathrm{C}$ method. In the present study, we identified six level terraces based on previous studies in this area including the characteristics of fluvial sediment and geomorphology, and dated the higher terraces (T3 to T6) using ESR signals in quartz. Thus, we took seven ESR samples from T3 to T6 in the Wenchuan profile (Fig. 2). The sampling method is similar as that for OSL dating. We used a stainless tube to keep the sediment sample, and sealed and protected from light.

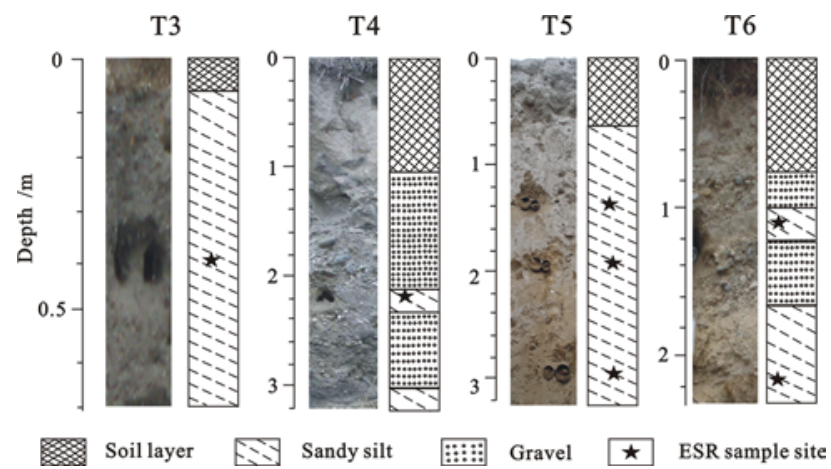

Fig. 2. Stratigraphy of different terrace layer in the Wenchuan profile, on the upper reach of the Minjiang River at the east margin of the Tibetan plateau and ESR sampling location.

\section{QUARTZ EXTRACTION AND ESR MEASURE- MENT}

The sample was dried at low temperature. The $105-200 \mu \mathrm{m}$ fraction was separated by sieving and pure quartz was obtained through chemical separation techniques (Liu et al., 2010a; Liu and Grün, 2011). After drying, the samples were soaked in $15 \% \mathrm{H}_{2} \mathrm{O}_{2}$ for $1 \mathrm{~h}$ followed by heavy liquid separation using sodium polytungstate. The samples were then etched by $40 \% \mathrm{HF}$ for $100 \mathrm{~min}$ followed by $10 \% \mathrm{HCl}$ for $100 \mathrm{~min}$. Magnetic minerals were removed using a magnetic separator after drying. At the end, the grains $<90 \mu \mathrm{m}$ were removed by sieving. Each sample was divided into $200 \mathrm{mg}$ subsamples. These aliquots have received additional gamma doses ranging from 0 to $6500 \mathrm{~Gy}$ using the ${ }^{60} \mathrm{Co}$ source of Peking University, Beijing.

The quartz Ti-Li center ESR signal intensity was measured for samples by a BRUKER ER041XG X-band spectrometer at low temperature in a finger dewar cooled to $77 \mathrm{~K}$ with liquid nitrogen. The microwave power was $5 \mathrm{~mW}$, modulation amplitude was $0.16 \mathrm{mT}$, conversion factor was $20.48 \mathrm{~ms}$, time constant was $40.96 \mathrm{~ms}$ and spectrum resolution was 2048 bit (resulting in a total sweep time of $41.94 \mathrm{~s}$ ). The Ti-Li center intensity was measured from the top of the peak at $\mathrm{g}=1.979$ to the bottom at g=1.913 (Rink et al., 2007; Liu et al., 2010a), from P1 to P2 in Fig. 3. The angular dependence of the ESR signal due to the sample heterogeneity was taken into account. Each aliquot was measured with six rotations, in which scan six times after every $60^{\circ}$ azimuths rotation in the cavity, to obtain the average quartz $\mathrm{Ti}-\mathrm{Li}$ center ESR intensity.

The dose rate (D) was calculated from the concentrations of $\mathrm{U}$, Th and $\mathrm{K}$ of each sample (Aitken, 1998). U

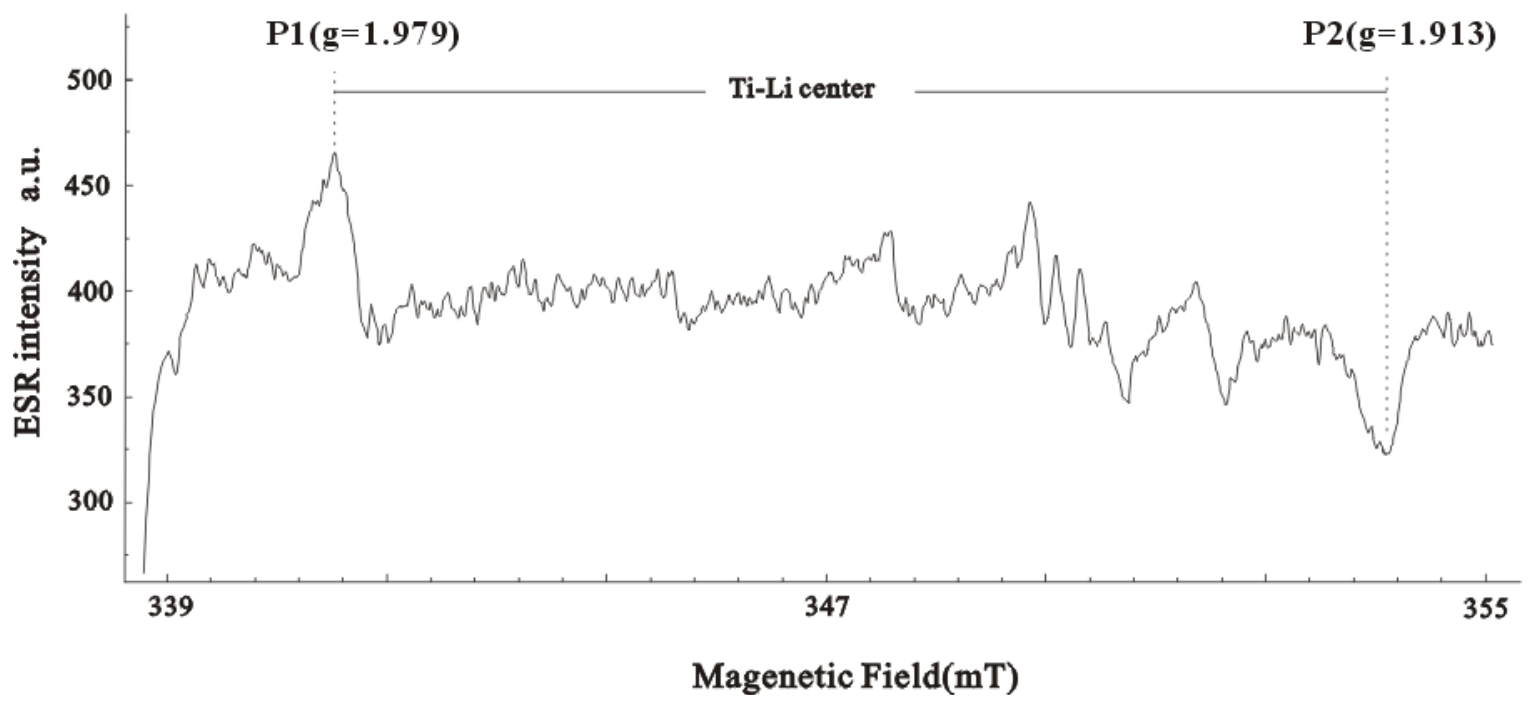

Fig. 3. ESR spectrum showing the method used to determine the intensity of the quartz Ti-Li center. This is the natural quartz Ti-Li center ESR spectrum of the sample MJ-4. 
and Th contents were obtained using a thick source Daybreak 530 Model alpha counter (Aitken, 1985, 1998). The potassium oxide content was determined by atomic absorption. The water content and grain sizes were considered during age calculation. Cosmic dose rates were calculated at the burial depth and altitude and latitude of the sample (Prescott and Hutton, 1994).

For all samples, the equivalent doses $\left(\mathrm{D}_{\mathrm{E}}\right)$ values and their individual errors were determined from the dose response data fitted with a single saturating exponential (SSE) function using the protocol described by Yokoyama et al. (1985). All $\mathrm{D}_{\mathrm{E}}$ values were obtained assuming complete bleaching.

\section{RESULT AND DISCUSSION}

Voinchet et al. (2007) investigated the natural bleaching of quartz ESR signals in modern sediment on the
Creuse River (France). The study showed, for the samples collected at about $170 \mathrm{~km}$ downstream from its source, that the bleaching of the Ti-Li center of quartz is practically complete and even a total bleaching is observed at $1 \mathrm{~km}$ downstream from the source. In the present study, the Wenchuan profile located at the upper reach of the Minjiang River (China) from its spring to about $200 \mathrm{~km}$ downstream. We took one modern sediment sample of the Minjiang River on the Wenchuan profile. Its quartz ESR spectrum showed that the Ti-Li center was totally bleached (Fig. 4). Hence, the assumption that the quartz Ti-Li center ESR signal is bleached to zero before the last sediment was validated.

Fig. 5 shows the dose responses of quartz ESR signal of Ti-Li center observed in the MJ-2 and MJ-3 samples. ESR data and ages of fluvial terraces obtained from the Wenchuan profile at the upper reach of the Minjiang River are shown in Table 1. The ESR ages of T3 and T4

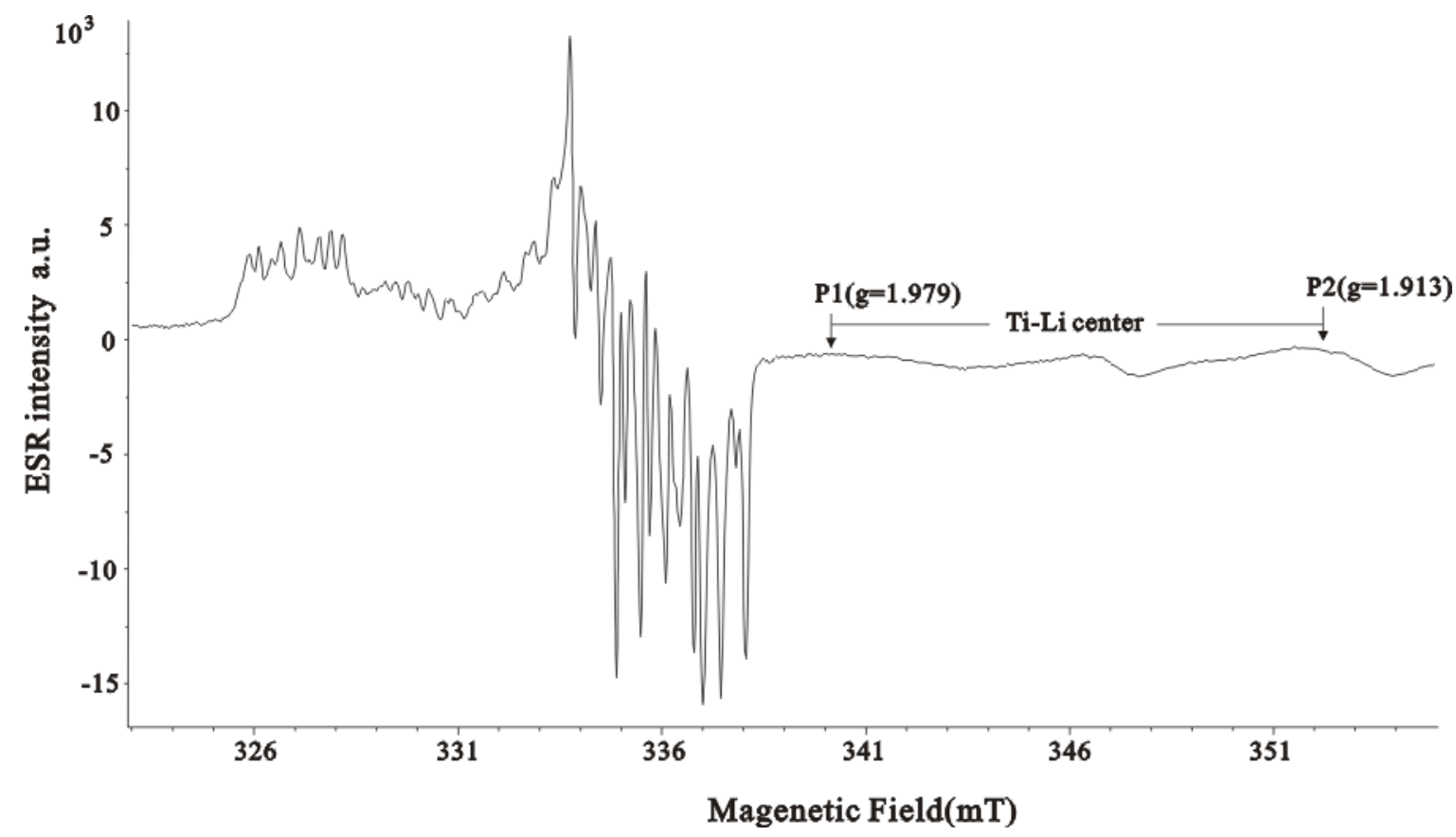

Fig. 4. ESR spectrum of the modern sediment sample of Minjiang River on the Wenchuan profile. The $g$ value of $T 1$ is 1.979 . The $g$ value of $T 2$ is 1.913.

Table 1. ESR dating results using quartz Ti-Li center signal from fluvial terrace samples of the Wenchuan profile on the upper reach of the Minjiang River, at the east margin of the Tibetan plateau. The elevation (column 2) is relative to river.

\begin{tabular}{|c|c|c|c|c|c|c|c|c|c|c|c|}
\hline $\begin{array}{c}\text { Sample } \\
\text { No. }\end{array}$ & $\begin{array}{l}\text { levation } \\
\text { (m) }\end{array}$ & $\begin{array}{c}\text { Depth } \\
\text { (m) }\end{array}$ & $\begin{array}{c}\mathbf{U} \\
(\mathrm{ppm})\end{array}$ & $\begin{array}{c}\text { Th } \\
\text { (ppm) }\end{array}$ & $\begin{array}{l}\mathrm{K}_{2} \mathrm{O} \\
(\%)\end{array}$ & $\begin{array}{c}\begin{array}{l}\text { Water } \\
(\%)\end{array} \\
\end{array}$ & $\begin{array}{l}\text { Cosmic dose } \\
\text { rate (Gy/ka) }\end{array}$ & $\begin{array}{c}D \\
\text { (Gy/ka) }\end{array}$ & $\begin{array}{c}D_{E} \\
(G y) \\
\end{array}$ & $\begin{array}{c}\begin{array}{c}\text { ESR age } \\
(\mathrm{ka})\end{array} \\
\end{array}$ & $\begin{array}{c}\text { Terrace } \\
\text { level }\end{array}$ \\
\hline MJ-1 & 172 & 1.2 & $4.9 \pm 0.3$ & $14.8 \pm 0.7$ & $2.70 \pm 0.14$ & $5 \pm 5$ & $0.208 \pm 0.011$ & $4.824 \pm 0.302$ & $2161 \pm 470$ & $450 \pm 102$ & \\
\hline MJ-2 & 172 & 2.2 & $4.3 \pm 0.2$ & $13.2 \pm 0.7$ & $2.80 \pm 0.14$ & $5 \pm 5$ & .010 & $4.631 \pm 0.291$ & $1828 \pm 576$ & $396 \pm 127$ & 16 \\
\hline MJ-3 & 153 & 1.4 & $4.6 \pm 0.3$ & $14.0 \pm 0.7$ & $2.40 \pm 0.12$ & $8 \pm 5$ & $0.203 \pm 0.011$ & $4.329 \pm 0.389$ & $624 \pm 106$ & $145 \pm 29$ & \\
\hline MJ-4 & 153 & 1.9 & $4.3 \pm 0.2$ & $13.0 \pm 0.7$ & $2.70 \pm 0.14$ & $10 \pm 5$ & $0.190 \pm 0.010$ & $4.334 \pm 0.466$ & $612 \pm 150$ & $143 \pm 38$ & T5 \\
\hline MJ-5 & 153 & 3.0 & $5.1 \pm 0.3$ & $15.5 \pm 0.8$ & $2.50 \pm 0.13$ & $10 \pm 5$ & 0.16 & $4.509 \pm 0.489$ & $762 \pm 130$ & $171 \pm 34$ & \\
\hline MJ-6 & 101 & 2.2 & $5.2 \pm 0.3$ & $16.1 \pm 0.8$ & $3.40 \pm 0.17$ & $4 \pm 4$ & 0.182 & $5.646 \pm 0.310$ & $568 \pm 79$ & $101 \pm 15$ & T4 \\
\hline MJ-7 & 75 & 0.4 & $4.6 \pm 0.3$ & $14.2 \pm 0.7$ & $3.30 \pm 0.17$ & $5 \pm 5$ & $0.232 \pm 0.012$ & $5.258 \pm 0.330$ & $336 \pm 80$ & $64 \pm 19$ & T3 \\
\hline
\end{tabular}


are $64 \pm 19 \mathrm{ka}$ and $101 \pm 15 \mathrm{ka}$ respectively. T3 age is consistent with the TL dating result $(50.8 \pm 3.9 \mathrm{ka})$ by Li et al. (2005) at the Wenchuan profile and (51-58 ka) by Ma et al. (2005) at the upper reach of the Minjiang River. Three T5 samples address the ages of $145 \pm 29 \mathrm{ka}, 143 \pm 38 \mathrm{ka}$, $171 \pm 34 \mathrm{ka}$, with the average of $153 \pm 33 \mathrm{ka}$. Our ESR results show that the ages of $\mathrm{T} 4$ and $\mathrm{T} 5$ at Wenchuan profile are older than the TL dating results $(57.2 \pm 4.3 \mathrm{ka}$ and $76.6 \pm 5.7 \mathrm{ka}$ ) on the Zipingpu (at Dujiangyan, in Fig. 1) by Li et al. (2005), and these results are consistent with the results that the incision rate is higher at the area of Longmen Shan than Sichuan Basin. The ages of two T6 samples are $450 \pm 102 \mathrm{ka}$ and $396 \pm 127 \mathrm{ka}$, with the average of $423 \pm 115$ ka (Fig. 6).

According to our ESR results (Fig. 7), two periods of incision are indicated: period one, from T6 to T5, took an average incision rate of $0.07 \mathrm{~mm} / \mathrm{a}$ and stage two, between T5 and T1, was $1.02 \mathrm{~mm} / \mathrm{a}$, which are consistent with the results from the north-east and north margins of the Tibetan Plateau (Li, 1991; Li et al., 1996; Porter et al., 1992; Pan et al., 2009; Liu et al., 2010b). The average incision rates of Yellow River near Zaoshugou (north of Lanzhou city, north-east of Tibet Plateau) are 0.033 and $0.346 \mathrm{~mm} / \mathrm{ka}$ at the period of 0.13-0.8 Ma and 0.13 Mapresent respectively (Pan et al., 2009). Therefore, the formation age of terrace at the Wenchuan profile is similar with north and north-east margin of the Tibet margin, and this indicated the spatial and temporal synchronization response to the overall uplifting of the Tibetan Plateau at the margin.

Tectonic movement of the Tibet plateau provides the base to formation of the terrace (Porter et al., 1992).
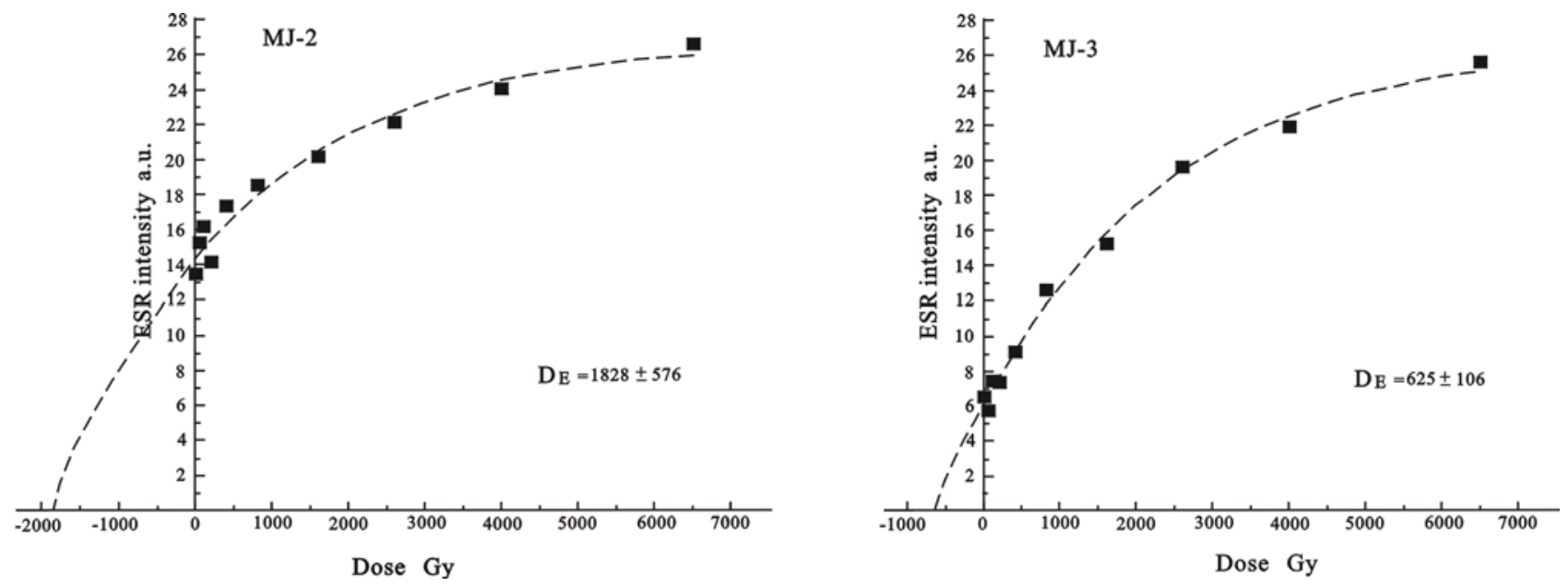

Fig. 5. The dose responses of quartz ESR signal of Ti-Li center observed in the MJ-2 and MJ-3 samples.

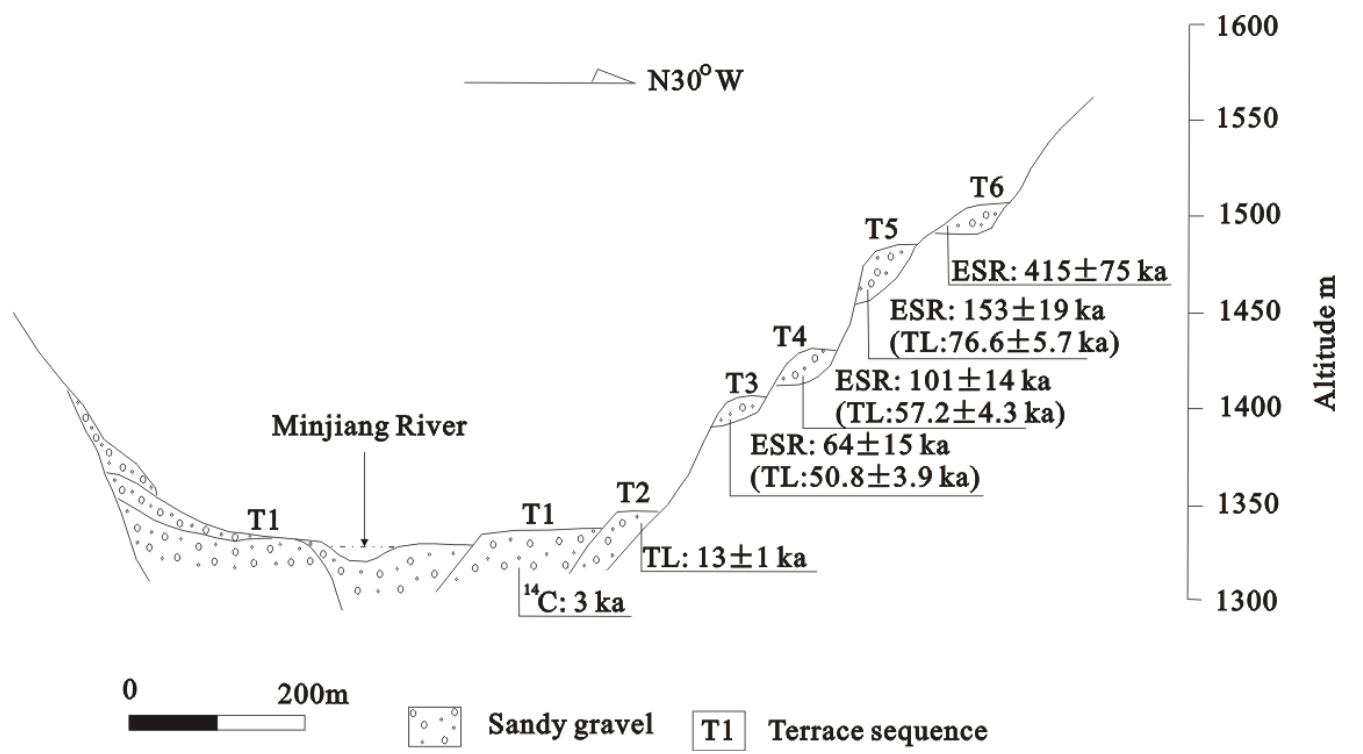

Fig. 6. The ages of fluvial terrace obtained from the Wenchuan profile on the upper reach of Minjiang River, at the east margin of the Tibetan plateau. The $T L$ and ${ }^{14} \mathrm{C}$ ages refer to $\mathrm{Li}$ et al. (2005). 


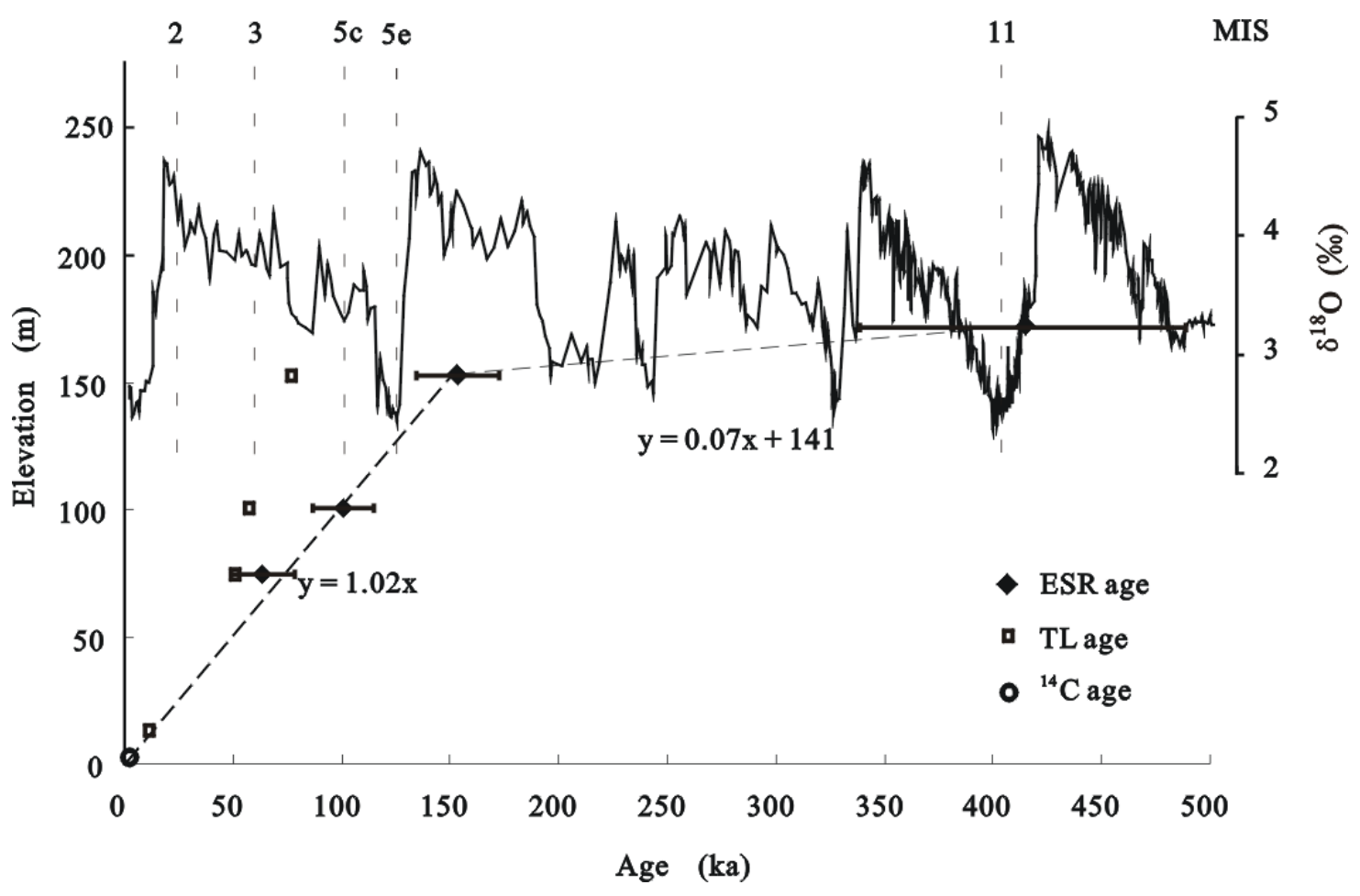

Fig. 7. The linear relationship observed between terrace elevations and the ages, with marine oxygen isotope changes (Alexander et al., 2009). The elevation is relative to river.

While the climate change does affect the terrace development, in this profile T2 addressed MIS2/1, T3 addressed MIS4/3, T4 is for MIS5d/5c, T5 is for MIS6/5e, which is consistent with the results at north margin $(\mathrm{Li}$, 1991, 1996; Liu et al., 2010b) and north-east margin (Porter et al., 1992) of the Tibet Plateau. This indicated synchronization with other areas of the Tibetan Plateau (Porter et al., 1992; Pan et al., 2009) and all these lay in glacial to interglacial transition periods as suggested by Pan et al. (2009). At Longmen Shan, moisture precipitation is mainly supported by Indian monsoon. During such climatic shift period, the Indian monsoon is strongly controlled by the change in the amount of the glacier at high latitude zone (An et al., 2011). At the entrance into an interglacial stage, the increase of precipitation due to the strengthened Indian Monsoon causes larger river incision and forms the terraces if this incision is associated with tectonic uplift.

In Qilian and Lanzhou region, no terrace was discovered between $830 \mathrm{ka}$ and $130 \mathrm{ka}$ accounting for the climate change (Pan et al., 2009). It was suggested that, without rapid tectonic uplift, climate change did not form stepped terrace systems at the margin of the Tibet Plateau (Pan et al., 2009). However, at the Minjiang River, an age of $423 \pm 115 \mathrm{ka}$, which can be correlated with MIS12/11 period, was obtained for T6 for the first time in this region. An older river terrace, documented by $\mathrm{Xu}$ and $\mathrm{Zhou}$ (2008) at the Yazheku River, at the eastern margin, was addressed to MIS16. It implies that additional uplifting phases could be taken into account. At the east margin of the Tibet Plateau, Longmen Shan area contains regional erosion uplifting due to the isostasy as suggested by Li et al. (2005). This regional uplifting caused by erosion could be temporarily accelerated by the rapid melting of glacier and strengthen of precipitation with regional enhancement of erosion rate during the transition of glacial to interglacial period. This could be another nonnegligible driving factor for terrace formations in this region.

\section{CONCLUSION}

Six terrace levels were investigated in the Wenchuan profile at the upper reach of Minjiang River. The ESR dating method was used to obtain the age of the four higher terraces (T3-T6). Combined with previous research, it showed that T1-T5 was formed since $150 \mathrm{ka}$ ago and T6 was formed at MIS12/11 stage. Both tectonic and climate influenced the formation of these terraces. The river terrace formation exit high synchronization with the uplifting of the Tibet plateau at the different margins. Apart from the whole uplifting of the Tibet plateau, the rapid uplifting due to isostasy is an additional regional tectonic factor to form the terrace in the eastern margin of the Tibetan plateau. 


\section{ACKNOWLEDGEMENTS}

This research was supported by the basic scientific research fund, Institute of Geology, China Earthquake Administration (Grant No. IGCEA1216), and the National Science Foundation of China (Grant No. 40902051, 41372178, 41030317 and 40841013), and State Key Laboratory of Earthquake Dynamics, Institute of Geology, China Earthquake Administration (Grant No. LED2009A04), and the French Chinese PHC "Cai Yuanpei” program (EGIDE-MAEE). We are very glad to thank Prof. Rainer Grün, Research School of Earth Sciences, The Australian National University, Canberra, Australia, for sampling and discussions.

\section{REFERENCES}

Aitken MJ, 1985. Thermoluminescence Dating. London: Academic Press.

Aitken MJ, 1998. An Introduction to Optical Dating. Loondon: Oxford University Press.

Alexander JD, Christopher JB, Ciara D, Mark AM, James AB, Erin LM and Richard DP, 2009. Oceanic forcing of the Marine Isotope Stage 11 interglacial. Nature Geoscience 2(6): 428-433, DOI 10.1038/ngeo527.

An ZS, Steven CC,Shen J, Qiang XK, Jin ZD, Sun YB, Prell WL, Luo JJ, Wang S,Xu H, Cai YJ, Zhou WJ, Liu XD, Liu WG, Shi ZG, Yan LB, Xiao XY, Chang H,Wu F, Ai L and Lu FY, 2011. Glacial-interglacial Indian summer monsoon dynamics. Science 333: 719-723, DOI 10.1126/science.1203752.

Beerten K, Lomax J, Clémer K, Stesmans A and Radtke U, 2006. On the use of Ti centres for estimating burial ages of Pleistocene sedimentary quartz: multiple grain data from Australia. Quaternary Geochronology $\quad 1(2): \quad 151-158, \quad$ DOI 10.1016/j.quageo.2006.05.037.

Bridgland DR, 2000. River terrace systems in north-west Europe: an archive of environmental change, uplift and early human occupation. Quaternary Science Reviews 19(13): 1293-1303, DOI 10.1016/S0277-3791(99)00095-5.

Brocard GY, Beek PA, Bourles DL, Siame LL and Mugnier JL, 2003. Long-term fluvial incision rates and post glacial river relation time in the French Western Alps from ${ }^{10} \mathrm{Be}$ dating of alluvial terraces with assessment of inheritance, soil development and wind ablation effects. Earth and Planetary Science Letters 209(1-2): 197214, DOI 10.1016/S0012-821X(03)00031-1.

Burchfiel BC, Chen Z, Liu Y and Royden LH, 1995. Tectonics of the Longmen Shan and adjacent regions. International Geology Review 37(8): 661-735, DOI 10.1080/00206819509465424.

Burchfiel BC, Royden LH, vander Hilst RD, Hager BH, Chen Z, King RW, Li C, Lü J, Yao H and Kirby E, 2008. A geological and geophysical context for the Wenchuan earthquake of 12 May 2008, Sichuan. People's Republic of China, GSA Today 18: 4-11, DOI 10.1130/GSATG18A.1.

Chen SF, Wilson CJL and Worley BA, 1995. Tectonic transition from the Songpan-Garze fold belt to the Sichuan Basin, southwestern China. Basin Research 7(3): 235-253, DOI 10.1111/j.13652117.1995.tb00108.x.

Chen SF and Wilson CJL, 1996. Emplacement of the Longmen Shan Thrust-Nappe Belt along the eastern margin of the Tibetan Plateau. Journal of Structural Geology 18(4): 413-430, DOI 10.1016/0191-8141(95)00096-V.

Chen Z, Burchfiel BC, Liu Y, King RW, Royden LH, Tang W, Wang E, Zhao J and Zhang X, 2000. Global Positioning System measurements from eastern Tibet and their implications for India/Eurasia intercontinental deformation. Journal of Geophysical Research: Solid Earth 105(B7): 16215-16227, DOI 10.1029/2000JB900092.
Dirks P, Wilson CJL, Chen S, Luo ZL and Liu S, 1994. Tectonic evolution of the NE margin of the Tibetan Plateau: evidence from the central Longmen Mountains, Sichuan Province, China. Journal of Southeast Asian Earth Sciences 9(1-2): 181-192, DOI 10.1016/0743-9547(94)90074-4.

Gao L, Yin GM, Liu CR, Lin M and Li JP, 2009. Nature sunlight bleaching of the ESR titanium center quartz. Radiation Measurements 44(5-6): 501-504, 10.1016/j.radmeas.2009.03.033.

Godard V, Pik R, Lavé J, Cattin R, Tibari B, de Sigoyer J, Pubellier M and Zhu J, 2009. Late Cenozoic evolution of the central Longmen Shan, eastern Tibet: Insight from (U-Th)/He thermochronometry. Tectonics 28(5): TC5009, DOI 10.1029/2008TC002407.

King RW, Shen F, Burchfiel BC,Royden LH, Wang E, Chen ZL, Liu YP, Zhang XY and Zhao JX, 1997. Geodetic measurements of crustal motion in southwest China. Geology 25(2): 179-182, DOI 10.1130/0091-7613(1997)025<0179:GMOCMI >2.3.CO;2.

Kirby E, Reiners PW, Krol MA, Whipple KX, Hodges KV, Farley KA Tang WQ and Chen ZL, 2002. Late Cenozoic evolution of the eastern margin of the Tibetan Plateau: inferences from ${ }^{40} \mathrm{Ar} /{ }^{39} \mathrm{Ar}$ and (U-Th)/He thermochronology. Tectonics 21(1): 1-1-1-20, DOI 10.1029/2000TC001246.

Laurent M, Falguères C, Bahain JJ, Rousseau L and Van Vliet Lanoe B, 1998. ESR dating of quartz extracted from Quaternary and Neogene sediments: method, potential and actual limits. Quaternary Science Reviews 17(11): 1057-1061, DOI 10.1016/S02773791(97)00101-7.

Li JJ, 1991. The environmental effects of uplift of the Qinghai-Xizang Plateau. Quaternary Science Reviews 10(6): 479-483, DOI 10.1016/0277-3791(91)90041-R.

Li JJ, Fang XM, Ma HZ, Zhu JJ, Pan BT and Chen HL, 1996. Geomorphologic and environmental evolution in the upper reaches of Yellow River during the Late Cenozoic. Science in China, Series D 39: 380-390.

Li Y, Cao SY, Zhou RJ, Densmore AL and Ellis MA, 2005. Late Cenozoic Minjiang incision rate and its constraint on the uplift of the eastern margin of Tibet plateau. Acta Geologica Sinica 79(1): 2837.

Li Y, Zhou RJ, Densmore AL and Ellis MA, 2006. Geomorphic evidence for the late Cenozoic strike-slipping and thrusting in Longmeng Mountain at the eastern margin of the Tibetan Plateau. Quaternary Sciences 26(1): 40-51.

Liu CR, Yin GM, Gao L, Bahain JJ, Li JP, Lin M and Chen SM, 2010a. ESR dating of Pleistoncene archaeological localities of the Nihewan Basin, North China-Preliminary results. Quaternary Geochronology 5(2-3): 385-390, DOI 10.1016/j.quageo.2009.05.006.

Liu CR and Grün R, 2011. Fluvio-mechanical resetting of the $\mathrm{Al}$ and $\mathrm{Ti}$ centres in quartz. Radiation Measurements 46(10): 1038-1042, DOI 10.1016/j.radmeas.2011.06.076.

Liu XF, Li YM, Liu HC, Gao HS, Pan BT, Li BX and Fan B, 2010b. Response of Weihe River to climatic change in Longxi zone. Journal of Arid Land Resources and Environment 24(11): 68-72.

Ma BQ, Su G, Hou ZH and Shu SB, 2005. Late quaternary slip rate in the central part of the Longmengshan fault zone from terrace deformation along the Minjiang River. Seismology and Geology 27(2): 234-242.

Maddy D, 1997. Uplift-driven valley incision and river terrace formation in southern England. Journal of Quaternary Science 12(6): 539-545, DOI 10.1002/(SICI)1099 1417(199711/12)12:6<539::AID-JQS350>3.0.CO;2-T.

Molnar P, 2005. Mio-Pliocene growth of the Tibetan Plateau and evolution of East Asian climate. Palaeontologia Electronica 8(1).

Moreno D, Falguères C, Perez-Gonzalez A, Duval M, Voinchet $\mathrm{P}$, Benito-Calvo A, Ortega AI, Bahain JJ, Sala R, Carbonell E, Bermudez de Castro JM and Arsuaga JL, 2012. ESR chronology of alluvial deposits in the Arlanzon valley (Atapuerca, Spain): contemporaneity with Atapuerca Gran Dolina site. Quaternary Geochronology 10: 418-423, DOI 10.1016/j.quageo.2012.04.018.

Pan BT, Su H, Hu ZB, Hu XF, Gao HS, Li JJ and Kirby E, 2009. Evaluating the role of climate and tectonics during non-steady incision of the Yellow River: evidence from a 1.24 Ma terrace record near 
Lanzhou, China. Quaternary Science Reviews 28(27-28): 32813290, DOI 10.1016/j.quascirev.2009.09.003.

Pinter N and Brandon MT, 2005. How erosion builds mountains. Scientific American Special 15(2): 74-81.

Porter S, An ZS and Zheng HB, 1992. Cyclic Quaternary alluviation and terracing in a Nonglaciated drainage basin in the north flank of the QinlianShan Central China. Quaternary Research 38(2): 157169, DOI 10.1016/0033-5894(92)90053-L.

Prescott JR and Hutton JT, 1994. Cosmic ray contributions to dose rates for luminescence and ESR dating: Large depths and long-term time variations. Radiation Measurements 23(2-3): 497-500, DOI 10.1016/1350-4487(94)90086-8.

Rink WJ, Bartoll J, Schwarcz HP, Shane P and Ber-Yosef O, 2007. Testing the reliability of ESR dating of optically exposed buried quartz sediments. Radiation Measurements 42(10): 1618-1626, DOI 10.1016/j.radmeas.2007.09.005.

Royden LH, Burchfiel BC, King RW, Wang E, Chen ZL, Shen F and Liu YP, 1997. Surface deformation and lower crustal flow in eastern Tibet. Science 276: 788-790, DOI 10.1126/science. 276.5313 .788 .

Schumm SA and Parker RS, 1973. Implications of complex response of drainage systems for Quaternary alluvial stratigraphy. Nature Physical Science 243: 99-100, DOI 10.1038/physci243099a0.

Tanaka K, Machette MN, Crone AJ and Bowman JR, 1995. ESR dating of aeolian sand near Tennant Creek, Northern Territory, Australia. Quaternary Science Reviews 14(4): 385-393, DOI 10.1016/02773791(95)00032-1.

Tissoux H, Falguères C, Voinchet $\mathrm{P}$, Toyoda $\mathrm{S}$, Bahain $\mathrm{JJ}$ and Despriee J, 2007. Potential use of Ti-center in ESR dating of fluvial sediment. Quaternary Geochronology 2(1-4): 367-372, DOI 10.1016/j.quageo.2006.04.006.

Tissoux H, Toyoda S, Falguères C, Voinchet $\mathrm{P}$, Takada M, Bahain JJ and Despriee J, 2008. ESR dating of sedimentary quartz from two Pleistocene deposits using Al and Ti-centers. Geochronometria 30: 23-31, DOI 10.2478/v10003-008-0004-y.
Toyoda S, Voinchet P, Falguères C, Dolo JM and Laurent M, 2000. Bleaching of ESR signals by the sunlight: a laboratory experiment for establishing the ESR dating of sediments. Applied Radiation and Isotopes 52(5): 1357-1362, DOI 10.1016/S09698043(00)00095-6.

Voinchet $\mathrm{P}$, Bahain JJ, Falguères C, Laurent M, Dolo JM, Despriee J, Gageonnet R and Chausse C, 2004. ESR dating quartz extracted from quaternary sediments application to fluvial terraces system of morthern France. Quaternaire 15(1-2): 135-141.

Voinchet $\mathrm{P}$, Falguères $\mathrm{C}$, Tissoux $\mathrm{H}$, Jean-Jacques Bahain, Jackie Despriée and Florence Pirouelle, 2007. ESR dating of fluvial quartz: Estimate of the minimal distance transport required for getting a maximum optical bleaching. Quaternary Geochronology 2(1-4): 363-366, DOI 10.1016/j.quageo.2006.04.010.

Voinchet $\mathrm{P}$, Despriee J, Tissoux H, F alguères $\mathrm{C}$, Bahain JJ, Gageonnet R, Depont J and Dolo JM, 2010. ESR chronology of alluvial deposits and first human settlements of the Middle Loire Basin (Region Centre, France). Quaternary Geochronology 2(1-4): 381-384, DOI 10.1016/j.quageo.2006.03.011.

Xu LB and Zhou SZ, 2008. Influence of tectonic uplift and climate changes the Yazheku River terraces in the Eastern Tibetan Plateau. Acta Geologica Sinica 82(2): 269-280.

Yokoyama Y, Falguères C and Quaegebeur JP, 1985. ESR dating of quartz from quaternary s ediments: first attempt. Nuclear Tracks and Radiation Measurements 10(4-6): 921-928, DOI 10.1016/0735-245X(85)90109-7.

Zhang HP, Zhang PZ, Kirby E, Yin JH, Liu CR and Yu GH, 2011. Along-strike topographic variation of the Longmen Shan and its significance for landscape evolution along the eastern Tibetan Plateau. Journal of Asian Earth Sciences 40(4): 855-864, DOI 10.1016/j.jseaes.2010.05.015.

Zhang PZ, Shen Z, Wang M, Gan WJ, Burgman R, Molnar P, Wang Q, Niu ZJ, Sun JZ, Wu JC, Sun HR and You XZ, 2004. Continuous deformation of the Tibetan Plateau constrained from Global Positioning measurements. Geology 32(9): 809-812, DOI $10.1130 / \mathrm{G} 20554.1$ 